\title{
Spiritual Emotional Freedom Technique (SEFT) Therapy in Stress and Traumatic During the Pandemic Covid-19: A Literature Review
}

\author{
Retna Tri Astuti ${ }^{1}$, Suryo Ediyono ${ }^{2}$ \\ \{retnatriastuti@ummgl.ac.id ${ }^{1}$ \} \\ Faculty of Health Science, Universitas Muhammadiyah Magelang, Magelang, Indonesia ${ }^{1}$ \\ Faculty of cultural science University of Sebelas Maret, Indonesia ${ }^{2}$
}

\begin{abstract}
The Covid-19 that occurred in Indonesia had an impact not only on physical, economic aspects but also resulted in psychological problems such as stress and traumatics on society. It is necessary to make efforts to prevent and control stress and traumatic disorders. Spiritual Emotion Freedom Teqnique (SEFT) is a therapy developed from spiritual therapy and psychotherapy that can be used to manage stress and traumatic stress. The purpose of this literature review is to provide a description regarding the development of Spiritual Emotional Freedom Technique (SEFT) therapy as a stress and traumatic management therapy during the Covid-19 . Database searches via ScienceDirect, Pubmed and GoogleScholar. The keywords used in the search for this article were Spiritual Emotional Freedom Technique (SEFT), Stress, Traumatic, Covid-19 by getting 40 articles and only 6 articles used were used through objective analysis, topic suitability, research method used, size. samples, research ethics, the results of each article, and the limitations that occur. There are effective results of using Spiritual Emotional Therapy Fredom Technique in dealing with stress and traumatics during the Covid-19.
\end{abstract}

Keywords: Spiritual emotional freedom technique, Therapy, Stress, Covid-19

\section{Introduction}

The Covid-19 pandemic is a health emergency experienced by all people in the world that has the potential to seriously affect public health, including mental health [1]. The health emergency during the Covid-19 pandemic caused adverse psychological consequences and this lasted a long time due to anxiety, stress, trauma-related illness, large-scale social isolation and also because of information on social media [2], [3]. The results of research conducted by Wang et.al [4] in China with 1210 respondents found that anxiety levels were $30 \%$ and depression was $17 \%$. While the results of research by Qiu et. al, the results of a national survey involving 75 more than 50,000 respondents in China, found that nearly 35\% of participants experienced symptoms of stress related to trauma with women and young adults showed higher psychological pressure [5], [6].

The psychological symptoms that arise will interfere with the daily life of the individual. This of course requires action to prevent and control stress and traumatics during the Covid-19 pandemic. Many therapies are used to reduce psychological problems such as stress and 
traumatics, one of the therapies that can be used is the Spiritual Emotional Freedom technique (SEFT). Spiritual Emotional Freedom technique (SEFT) is a method that uses the energy in the individual's body to control and eliminate problems experienced.

The results of research conducted by Astuti and Amin show that SEFT therapy can reduce levels of stress and PTSD due to the Merapi disaster, results of research by Dewi and Fauziah on the effect of SEFT therapy on drug users and the results of research by Chodijah, Nurjannah, Yuliyanti states that SEFT therapy can be used as a therapy to overcome anxiety in facing Covid-19 [7]- [9]. SEFT therapy has many benefits that can help people overcome physical and psychological problems. The results of this literature review can be an alternative for nurses and other health workers to overcome psychological problems experienced during the Covid-19 pandemic.

\section{Method}

The research method used in this literature review uses a comprehensive strategy by searching through the internet. Searching through databases used includes ScienceDirect, Pubmed and Google Scholar during 2020. The keywords used in the search for articles were Spiritual Emotional Freedom Technique (SEFT), spiritual therapy, stress, traumatic, covid-19. There were 40 articles obtained and 6 articles analyzed through objective analysis, topic suitability, research methods used, sample size, the results of each article and the limitations that occurred.

\section{Results and Discussion}

The results of the literature review obtained can be seen in Table 1.

Table 1. Literature review

\begin{tabular}{|c|c|c|c|c|}
\hline Researcher & Title & Sample & Method & Output \\
\hline Dubey, et.al & $\begin{array}{l}\text { Psychosocial impact } \\
\text { of Covid-19 }\end{array}$ & $\begin{array}{l}\text { some } \\
\text { abstract }\end{array}$ & $\begin{array}{l}\text { Article } \\
\text { review }\end{array}$ & $\begin{array}{l}\text { Disease itself multiplied by forced } \\
\text { quarantine to combat COVID-19 } \\
\text { applied by nationwide lockdowns can } \\
\text { produce acute panic, anxiety, obsessive } \\
\text { behaviors, hoarding, paranoia, and } \\
\text { depression, and post-traumatic stress } \\
\text { disorder (PTSD) in the long run. }\end{array}$ \\
\hline Leilei Liang, et.al & $\begin{array}{l}\text { The Effect of Covid- } \\
19 \text { on Youth Mental } \\
\text { Health }\end{array}$ & 584 & $\begin{array}{l}\text { Cross } \\
\text { sectional }\end{array}$ & $\begin{array}{l}\text { Nearly } 40.4 \% \text { the sampled youth were } \\
\text { found to be prone to psychological } \\
\text { problems and } 14.4 \% \text { the sampled youth } \\
\text { with Post-traumatic stress disorder } \\
\text { (PTSD) symptoms. Univariate logistic } \\
\text { regression revealed that youth mental } \\
\text { health was significantly related to being } \\
\text { less educated (OR }=8.71,95 \% \text { CI: } 1.97- \\
38.43 \text { ), being the enterprise employee } \\
\text { (OR=2.36, } \\
\text { suffering from the PTSD symptom (OR } \\
=1.05 \text {, 95\%CI: } 1.03-1.07) \text { and using } \\
\text { negative coping styles (OR }=1.03 \text {, }\end{array}$ \\
\hline
\end{tabular}




\begin{tabular}{|c|c|c|c|c|}
\hline Researcher & Title & Sample & Method & Output \\
\hline & & & & $\begin{array}{l}95 \% \text { CI: } 1.00-1.07) \text {. Results of this study } \\
\text { suggest that nearly } 40.4 \% \text { of the youth } \\
\text { group had a tendency to have } \\
\text { psychological problems. }\end{array}$ \\
\hline Chodijah, et.al & $\begin{array}{l}\text { SEFT } \quad \text { Sebagai } \\
\text { Terapi Mengatasi } \\
\text { Kecemasan } \\
\text { Menghadapi Covid- } \\
19\end{array}$ & $\begin{array}{l}\text { several } \\
\text { participants }\end{array}$ & Kualitatif & $\begin{array}{l}\text { Anxiety can be interpreted as a } \\
\text { condition in which the individual who } \\
\text { experiences it feels inadequate, helpless } \\
\text { and depressed over an object that is } \\
\text { specifically unclear. Meanwhile, SEFT } \\
\text { is a contemporary therapeutic technique } \\
\text { that aims to eliminate or liberate } \\
\text { individuals spiritually and emotionally } \\
\text { from negative conditions. The results of } \\
\text { trials on clients show that by using the } \\
\text { proper stages of SEFT therapy, the } \\
\text { client's anxiety level decreases, so that it } \\
\text { can be recommended to be used more } \\
\text { widely in the community. } \\
\text { experiencing anxiety due to this covid- } \\
19 \text { virus pandemic }\end{array}$ \\
\hline Hasan, et.al & $\begin{array}{l}\text { Mujahadah Al Nafs } \\
\text { Among } \text { Covid-19 } \\
\text { Patients } \\
\text { Quarantine }\end{array}$ & $\begin{array}{l}\text { Several } \\
\text { participant }\end{array}$ & Kualitatif & $\begin{array}{l}\text { The results showed that there were } 22 \\
\text { types of problematic behaviors } \\
\text { exhibited by victims in quarantine } \\
\text { place. This negative phenomenon } \\
\text { requires a solution. The findings also } \\
\text { indicated that there are several spiritual } \\
\text { treatment approaches used in quarantine } \\
\text { place such as prayers, reciting the al- } \\
\text { Quran, fasting, zikir, self-reflection and } \\
\text { religious classes. }\end{array}$ \\
\hline Hakhu & $\begin{array}{l}\text { Spiritual Approach } \\
\text { Model: A Study } \\
\text { with } \quad \text { Special } \\
\text { Reference to Covid- } \\
19 \text { in India }\end{array}$ & 116 & $\begin{array}{l}\text { Survey } \\
\text { analysis }\end{array}$ & $\begin{array}{l}\text { The results of the present study } \\
\text { highlight that Spiritual Approach Model } \\
\text { is still at initial stage. It can be } \\
\text { concluded that the state of mind of } \\
\text { people of India amidst COVID-19 has a } \\
\text { assortment of challenges. The best } \\
\text { possible efforts are put in by individuals } \\
\text { to carry on with the actions for trying to } \\
\text { survive in the present day } \\
\text { circumstances. To achieve more peace } \\
\text { and devotion, it is suggested that Faith } \\
\text { in God has an undeviating bond. } \\
\text { Further, as per Figure 4, it is evident that } \\
\text { interconnect of Peace Characteristics } \\
\text { and Devotion Characteristics has a } \\
\text { comprehensive connect with Faith } \\
\text { Characteristics which emphasizes to } \\
\text { append the conviction to be focused for } \\
\text { a belief in retreating of COVID- } 19 \text { from } \\
\text { the globe. }\end{array}$ \\
\hline
\end{tabular}




\begin{tabular}{|c|c|c|c|c|}
\hline Researcher & Title & Sample & Method & Output \\
\hline Jamawi & $\begin{array}{l}\text { Mengelola Cemas di } \\
\text { Tengah Pandemik } \\
\text { Corona }\end{array}$ & $\begin{array}{l}\text { Some } \\
\text { abstract }\end{array}$ & $\begin{array}{l}\text { Literatur } \\
\text { review }\end{array}$ & $\begin{array}{l}\text { Various efforts have been made to } \\
\text { eliminate the increasing number of } \\
\text { casualties, including through education } \\
\text { regarding Corona and transmission, } \\
\text { prevention and termination of viral } \\
\text { infections through social distancing, } \\
\text { washing hands with soap, and keeping } \\
\text { activities at home and maintaining body } \\
\text { immunity through nutritious eating, } \\
\text { intense exercise moderate, and get } \\
\text { enough rest. Comprehensive } \\
\text { understanding regarding stressors, } \\
\text { namely the Corona or Covid virus.19 } \\
\text { combined with simple psychotherapy } \\
\text { such as relaxation, assist therapy, play } \\
\text { therapy, Spiritual emotional Freedome } \\
\text { Teqnnique (SEFT) and Islamic therapy } \\
\text { through Wudhuk, Prayers and } \\
\text { Forbearance to present sakinah in } \\
\text { yourself is a wise choice in manage } \\
\text { anxious. }\end{array}$ \\
\hline
\end{tabular}

\subsection{Discussion}

Effective management of stress and traumatic problems that occurred during Covid-19 can help people adapt to new changes. The current recommendations that the government has made, such as implementing health protocols, eating nutritious food, exercising and taking care of the psychology are very much needed to prevent the spread of Covid-19. Research on the use of Spiritual Emotional Freedom Technique (SEFT) therapy has been widely explained that this therapy is a holistic therapy which involves spiritual healing and other psychological therapies that can be tested for their effectiveness in overcoming stress and traumatic problems during the Covid-19 pandemic [9]-[11].

The effectiveness of using Spiritual Emotional Freedom Technique (SEFT) therapy can be used as a reference research to be tested further with a larger number of respondents, both individually and in groups, and can be developed using a mixed method method in order to dig deeper into the effectiveness of this therapy.

Spiritual Emotional Freedom Technique (SEFT) is an application of spiritual healing models which can be developed by adjusting the beliefs and religion of the individual [12]. If the individual is Muslim, this therapy can use dhikr as a set-up method in its implementation [11]. Based on the results of several studies, it is stated that with the Covid-19 pandemic various negative thoughts will appear and cause psychological problems, this SEFT therapy will be able to relax and replace negative thoughts with positive thoughts where sincerity and persistence in asking for help from God will create peace in the individual self. This makes SEFT very effective. Besides this therapy is also cheap and easy to do by anyone. Therefore this therapy can be an alternative to prevent the occurrence of various psychological problems experienced by the community during the Covid-19 pandemic. 


\section{Conclusion}

The Spiritual Emotional Freedom Technique (SEFT) therapy can make one of the therapies for handling and controlling stress and traumatics effectively and efficiently during the Covid19 pandemic.

\section{References}

[1] W. H. Organization, Coronavirus disease 2019 (COVID-19): situation report, 82. apps.who.int, 2020.

[2] J. Erquicia et al., "Emotional impact of the Covid-19 pandemic on healthcare workers in one of the most important infection outbreaks in Europe.," Med. Clin. (English ed.), 2020.

[3] S. Dubey et al., "Psychosocial impact of COVID-19.," Diabetes Metab. Syndr., vol. 14, no. 5, hal. 779-788, 2020.

[4] H. Wang, Y. Liu, K. Hu, M. Zhang, M. Du, dan ..., "Healthcare workers' stress when caring for COVID-19 patients: An altruistic perspective," Nurs. ..., 2020.

[5] Y. Mo et al., "Anxiety of Nurses to support Wuhan in fighting against COVID-19 Epidemic and its Correlation With Work Stress and Social Support.," J. Clin. Nurs., 2020.

[6] L. Liang et al., "The Effect of COVID-19 on Youth Mental Health.," Psychiatr. Q., vol. 91, no. 3, hal. 841-852, 2020.

[7] R. T. Astuti, M. K. Amin, dan N. Purborini, "Efektifitas Terapi Spiritual Emotional Freedom Technique (SEFT) Untuk Menurunkan Tingkat Stress Pasca Bencana pada Warga Pasca Erupsi Merapi Tahun 2010," Proceeding 6th Univ. Res. Colloq. 2017 Seri Pendidik., vol. 1, no. 1, hal. 397400, 2017.

[8] Aisyiyah, "Pengaruh Terapi," J. Keperawatan 'Aisyiyah, vol. 4, no. 6, 2017.

[9] M. Chodijah, D. S. Nurjannah, A. Y. Yuliyanti, dan ..., "SEFT sebagai terapi mengatasi kecemasan menghadapi Covid-19," Karya Tulis Ilm. LPPM ....

[10] J. Jarnawi, "MENGELOLA CEMAS DI TENGAH PANDEMIK CORONA," At-Taujih Bimbing. dan Konseling Islam, 2020.

[11] Z. Rahman, "Mujāhadah al-nafs among covid 19 patients in quarantine," Int. J. Psychosoc. Rehabil., 2020.

[12] R. Hakhu, "Spiritual approach model: A study with special reference to COVID-19 in India," J. Xi' an Univ. Archit. Technol., vol. 12, no. 5, hal. 2237-2244, 2020. 